\title{
Article
}

\section{Understanding the Denial of Abuses of Human Rights connected to Sports Mega- Events}

\author{
Horne, John David
}

Available at http://clok.uclan.ac.uk/17857/

Horne, John David ORCID: 0000-0003-4389-8204 (2017) Understanding the Denial of Abuses of Human Rights connected to Sports Mega-Events. Leisure Studies, 36 . pp. 1-11. ISSN 0261-4367

It is advisable to refer to the publisher's version if you intend to cite from the work. http://dx.doi.org/10.1080/02614367.2017.1324512

For more information about UCLan's research in this area go to http://www.uclan.ac.uk/researchgroups/ and search for < name of research Group>.

For information about Research generally at UCLan please go to http://www.uclan.ac.uk/research/

All outputs in CLoK are protected by Intellectual Property Rights law, including Copyright law. Copyright, IPR and Moral Rights for the works on this site are retained by the individual authors and/or other copyright owners. Terms and conditions for use of this material are defined in the policies page.

\section{CLoK}

Central Lancashire online Knowledge www.clok.uclan.ac.uk

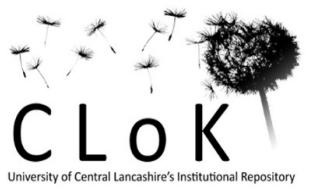


Understanding the Denial of Abuses of Human Rights connected to Sports Mega-Events ${ }^{i}$

John Horne

jdhorne@uclan.ac.uk

[Final accepted version]

Leisure Studies - published online May 2017]

http://www.tandfonline.com/doi/full/10.1080/02614367.2017.1324512

\begin{abstract}
Academics debate the positive and negative consequences of hosting sports mega-events, and although there is a general recognition that doing so cannot be a panacea for solving other social issues, who wins and who loses tends to be the same. This article considers why mega-events are not more regularly resisted given the routinisation of harm to local populations that they tend to invoke. It develops ideas derived from the late sociologist and criminologist Stanley Cohen concerning the relationships between, and the politics of, denial and acknowledgement, with specific attention to the role of academics, nongovernmental organizations (NGOs) and the media. The article illustrates the difficulties in exposing, contesting and transforming these human rights abuses, but suggests that there are grounds for optimism as new strategies for communicating human rights abuses in connection with sports mega-events are developed.
\end{abstract}

\title{
Introduction
}

This article attempts to develop a 'Cohenesque' framework for understanding contestation over human rights abuses connected to sports mega-events. That is; it explores some of the mechanics and politics of denial and acknowledgement that Stanley Cohen explored in States of Denial (2001), and elsewhere (see Cohen 2002, 1996). It seeks to illustrate the difficulties in exposing, contesting and transforming these human rights abuses. It thus links with the Special Issue's aim of providing insights into some of the dilemmas, questions and challenges facing human rights praxis. Academics have long debated the positive and negative consequences of hosting sports mega-events, often aided by the work of critical investigative journalists (Simson and Jennings 1992; Jennings 1996; 2006). Although there is a general recognition that mega-events cannot be a panacea for solving other social issues, who wins and who loses tends to be the same. As Zimbalist $(2015,122)$ suggests, 'Hosting sports mega-events...tends to reinforce the existing power structure and patterns of inequality'. 
The structure of the article is as follows. First the discourses involved in struggles over rights and sport, and especially sports mega-events, are outlined. Second Cohen's work on the politics of denial is briefly sketched. Third follows an account of recent discussions about human rights and other abuses connected to sports mega-events. The article then identifies and reflects on a number of reports about human rights abuses in connection with two mega-events, the FIFA World Cup held in Brazil 2014 (hereafter WC2014) and the Summer Olympic and Paralympic Games in 2016 (hereafter Rio 2016). Finally the article considers if the conditions conducive to the creation of successful moral panics about sports megaevents generally remain in the prevailing political and ideological climate.

\section{(Human) Rights Discourse and Sport}

Rights are seen as inherently political and contingent - taking institutional, legal and discursive forms. Many different struggles in varied social, economic, political and ideological contexts have been wrapped up under the phrase 'human rights'. Movements concerned with workers' rights, women's rights, peace, and the environment as well as specifically those involved in human rights campaigns, at different times and in different places, have involved struggles over civil, political, economic, social and cultural rights (Harvey et al 2014). The relationship of these campaigns to sport is sometimes organic, emerging from within sport, and sometimes more superficial, developing outside of sport. It is interesting to note that the development of the concept of human rights shares some of the tensions that underpinned the history of the formation of modern sport, including the Olympic movement, in the second half of the $19^{\text {th }}$ century (particularly that between internationalism and nationalism). Yet, no a priori assumption that sport can be a force for human good is supported by the historical evidence, as over the past 150 years sport has been responsible for many exclusionary practices and barriers that have in turn prompted negotiations and resistance (Donnelly 2008; Kidd and Donnelly 2000).

David Harvey (2012 p. 3) suggests that, 'we live in an era when ideals of human rights have moved center-stage both politically and ethically.' Why is that? One view of the formation of human rights discourse is that it is an 'invented tradition' (Hunt 2007) stemming from the print culture of the $18^{\text {th }}$ century which enabled a new sensibility and sensitivity to suffering to be communicated to the reading public, especially through the novel. Rather than focus on the formal reasoning of philosophical texts, it is possible that the creation of an 
awareness of wider humanity came about through the power of the imagination that aroused sympathy for oppression (Blackburn 2011). Hence broadly speaking concerns for human rights refers to concerns about injustice, discrimination and exploitation - or consciousness of humanity (Robertson, 1992) - and the desire for a better world.

Human rights however have a contested history because, although 'NGOS working for human rights are not new' (Freeman 2011, p. 167), as Samuel Moyn (2010, p. 20) puts it, the history of the core values of human rights is 'one of construction rather than discovery and contingency rather than necessity'. Moyn argues that the discourse of human rights only became predominant since 1977 because it provided an alternative to other failed 'utopian' projects and grand narratives. Moyn poses the question whether the relationship to previous 'human universalisms' should be seen as one of continuity or as rupture. Earlier claims to the 'rights of man' were the basis for the construction of the nation-state, whereas contemporary human rights discourse tends to be the basis for a critique of state repression and corporate exploitation.

It is valuable to be reminded that there are fluid boundaries around the concept of human rights, which means that at different moments in time and in different places, the term has been understood and acted upon quite differently. In addition to the formal human rights institutions, bodies and positions that have been established since the Universal Declaration of Human Rights in 1948 - and possibly comprising the more public face of human rights as part of a global, transnational, social movement - are international non-governmental organizations (INGOs) that monitor, promote and seek to protect human rights. The most well known of these are Amnesty International (AI), and Human (formerly Helsinki) Rights Watch (HRW). Human rights organizations such as Al and HRW arguably led the internationalization of social movements (Tilly 2004, p.115). They monitored human rights abuses across the world, published regular human rights ratings, reported on these abuses and intervened to call for sanctions from major states and international authorities on human rights abuses. They provided 'templates, certification, connections and advise to claimants' (Tilly 2004, p. 115). According to Tilly (2004, p. 115) movements of 'self-styled indigenous peoples across the world benefitted substantially from identification of themselves as participants in a worldwide cause'. Nonetheless, as Therborn (2011, p. 2) suggests, whilst human rights began to emerge as a serious issue in the 1960s, mainly 
thanks to the formation of groups such as Al, they only reached the 'geopolitical mainstream' in the 1970s:

The Western powers had them inserted in the Helsinki Accord of 1975, recognizing the post-Second World War borders of Europe, crucial to Poles and most other East Europeans, communist or anti-communist. In the Americas, human rights also became a key issue in the second half of the 1970s. In Latin America they became a defence in defeat, after all attempts at progressive social change (outside Cuba) had been crushed by military dictatorships. In the USA there was, for once, a positive resonance during the Carter administration. The completely unforeseen unlocking of Cold War diplomacy and US recognition of human rights in the Americas made human rights irremovable from the international political agenda, accepted in violation by the Reagan and the two Bush administrations.

Different movements, campaigns and coalitions therefore constitute the field of human rights. We agree with Stammers $(2009$, p. 160) that it is important to acknowledge the preinstitutional, non-legal forms that existed prior to human rights law and institutions as well as the role that social movement praxis plays in shaping intellectual developments around human rights.

Echoing Moyn above, sport scholar Susan Brownell (2012 p. 315) notes: 'human rights are not pre-given moral truths, they are constructions'. The formal apparatus of human rights and the social movements that espouse and promote human rights transnationally are constantly engaged in this work of construction in what is sometimes referred to as 'global civil society'. What makes human rights complex is that they are both transnational and intersectional - that is the different minorities and groups involved in separate struggles over rights draw inspiration from the activities of other groups acting inside and outside the boundaries of their nation-states. As Fraser (1997, pp. 69-98) argues, social movements are 'subaltern counter-public spheres', where oppositional interpretations of identities, interests and needs are debated, discussed and formulated. If the space of human rights discourse is transnational, how might Stanley Cohen's work be useful for understanding the denial of abuses of human rights in sports mega-events? 
Cohen's earliest research on folk devils and moral panics, investigating the social reaction to young people involved in the Mods and Rockers subcultures in England in the 1960s, revealed that the media play a key role in the struggle for socially just outcomes. Cohen suggests, moral panics might be seen as "condensed political struggles to control the means of cultural reproduction. Studying them ... allows us to identify and conceptualize the lines of power in any society, the ways we are manipulated into taking things too seriously and other things not seriously enough" (Cohen, 2002, p. xxxv). Social scientists have no privileged status in pointing this out and suggesting remedial policies - they are just another claims maker along with activists and critical investigative journalists - but they can expose 'under-reaction (apathy, denial and indifference)' and 'over-reaction (exaggeration, hysteria, prejudice and panic' (Cohen 2002, p. xxxiv). Additionally, he noted that some 'disparities are so gross, some claims so exaggerated, some political agendas so tendentious, that they can only be called something like..."social injustice"' (Cohen 2002, p. xxxiv).

In one of his last public lectures Cohen (2010) suggested that an 'atrocity quadrangle' might be used to identify the relationship between folk devils, moral panics, social control and denial (see Figure 1).

\section{Figure 1 A Human Rights Atrocity Quadrangle}

\begin{tabular}{|l|l|}
\hline $\begin{array}{l}\text { Human Rights Violation } \\
\text { [Folk Devil / Violators] }\end{array}$ & $\begin{array}{l}\text { Social control agency } \\
\text { [The state, municipal government] }\end{array}$ \\
\hline $\begin{array}{l}\text { Victims (Denied) } \\
\text { [The displaced, evicted, children, and/ or } \\
\text { marginalized people] }\end{array}$ & $\begin{array}{l}\text { Observers } \\
\text { (Audiences, journalists, campaigners, social }\end{array}$ \\
\hline
\end{tabular}

Whereas the concept of 'folk devil' focussed on the symbolic contestation over marginal/ deviant subcultures, 'moral panics' suggested the exaggerated coverage given to specific episodes/ issues involving them. 'Moral panic' suggests that something not fully deserving of important and lengthy treatment is acknowledged as critical. Cohen's States of Denial (2001) is subtitled 'knowing about atrocities and suffering'. Denial is about cover-up, evasion, and giving too little importance to some issue or concern. As Cohen noted, 'every personal life and every society is built on denial. Only an overriding principle - like social 
justice - can determine which forms of denial matters, which can be left alone' (Cohen 2001 p. 295).

In an interview Cohen said that "human rights may now be the last meta-narrative we have left"' (Cohen, quoted in Taylor 2007, p. 24). Elsewhere he wrote that: 'my own cultural politics entails...encouraging something like moral panics about mass atrocities and political suffering - and trying to expose the strategies of denial deployed to prevent the acknowledgement of these realities'. Moral panics can become a 'critical tool to expose dominant interests and ideologies' (Cohen, 2002, p. xxxiii).

Cohen $(2002 ; 2010)$ thus identifies the basis for a cultural politics of moral panics and suggests that anti-denial movements may seek to develop their own moral panics about injustices. There is a need to 'purposely recreate the conditions that made the Mods and Rockers panic so successful (exaggeration, sensitization, symbolization, prediction, etc.) and thereby overcome the barriers to denial, passivity and indifference that prevent a full acknowledgement of human cruelty and suffering' (Cohen, 2002, p. xxxiii). Cohen (2010) argued that we need denial; it indicates our connection with the social bond. Also for the same reason, moral panics may be useful as they remind us that there is a moral universe, and 'a moral universe in which hypocrisy occurs is probably better than not recognising a moral universe at all'. Previously denied realities should be brought to public attention, realities exposed, and consciousnesses-raised about the different elements that go into a social problem. This is the role of a moral panic about human rights abuses connected with sports mega-events that has been developing over the past 30-40 years and that transcends national media space.

\section{Human Rights Abuses and Sports Mega-Events}

The social impacts associated with the hosting of major events are extensive and well documented (Ritchie \& Hall 1999; Lenskyj 2002, 2008; Hayes \& Horne 2011) with the displacement of residents representing the most dramatic impact (Olds 1998; COHRE 2007; Porter et al. 2009; Rolnik 2009). Yet in 2004 following the Summer Olympic Games in Athens, and with Beijing the next host, Jacques Rogge, then President of the International 
Olympic Committee (IOC), made the comment that 'The IOC is always in favour of maximum application of human rights...But it is not up to the IOC to monitor human rights' (cited in Kelso 2004). Nonetheless the build up to Beijing 2008 over the next four years saw an unprecedented focus by campaigners on human rights. Seeking to use the first Olympics in China to highlight human rights abuses the official torch relay was subverted and the Centre on Housing Rights and Evictions (COHRE) in Geneva published a further dossier itemizing the displacements of hundreds of thousands of people to make way for the Beijing Games (COHRE 2008; on the torch relay see Horne and Whannel 2010).

Critical rights discourse has accompanied all sports mega-events that have taken place since 2008. For example an overview by Adams and Piekarz (2015) suggests that land use, sport and employment practices have formed the main foci of this discourse. In the Human Rights Watch Annual Report for 2015 Worden $(2015,1)$ identified five main human rights abuses that had been associated with sports mega-events:

1. The forced evictions of citizens without due process or compensation;

2. The abuse and exploitation of migrant workers;

3. The silencing of civil society and rights activists;

4. Threats, intimidation and arrest of journalists; and

5. Discrimination within nations competing to host or simply competing at the megaevents.

In addition to monitoring violations, rights advocacy actors have increasingly focused on sports mega-events helping to create what Timms (2017 pp. 108ff) refers to as the relay of mega-event activism'. Hence ahead of the 2014 FIFA World Cup and the 2016 Olympic and 
Paralympic Games in Rio de Janeiro, campaigners identified concerns over the rights of children, workers, women, the disabled, LGBT, marginal populations, the socially excluded, and the environment (World Cup and Olympics Popular Committee 2015).

When thousands of Brazilians took to the streets during the FIFA Confederations Cup in June 2013, for example, the then FIFA President Sepp Blatter said on national television that 'I can understand people are not happy but they should not use football to make their demands heard' (cited in Watts 2013). Yet symbolic transformations of urban environments to fit global expectations of modernity - expressing security, order, and economic success in vibrant, exciting, safe, places, 'open for business' - do tend to impact on the quality of life of inhabitants and most negatively on poor and marginal populations (Broudehoux 2016). Issues surrounding rights of access to facilities built at public expense, the removal of poor communities from housing and evictions, have created struggles over whom or what is (made) visible.

The year 2016 marked 52 years since a military coup d'état brought about a twenty-oneyear long period of dictatorship and 31 years since its replacement and re-democratization in Brazil. Unfortunately the instability of the political system and the economy stimulated further convulsions during 2016 as the President, Dilma Rousseff, was formally impeached during the weeks between the end of the Olympics and the start of the Paralympic Games. Globalization brings with it an amplification of existing contradictions in society and in contemporary Rio this was especially the case. ${ }^{\text {ii }}$

The social impacts and consequences of Olympic-related infrastructure projects have echoed previous historical episodes of urban transformation in Rio that had profound consequences for the city's poorest (Meade, 1997; McCann, 2014; Perlman, 2010). Between 1902 and 1906 Mayor Francisco Pereira Passos was credited with the wholesale transformation of Rio's central area. Another period of intense displacement took place in 
the 1960s during Rio Governor Carlos Lacerda's term of office. His pledge for transforming the urban space also translated into the wholesale removal of favelas in the South End of the city with families relocated to social housing projects such as Cidade de Deus in the then distant region of Barra (Silvestre 2016). This historical legacy has once again been repeated with the hosting of the 2016 Games contributing to the displacement of thousands of residents from favelas and low-income neighbourhoods.

The preparations for the Rio 2016 Games have accumulated a problematic track record in this respect as substantial parts of, and in some cases entire, favelas have been removed to make way for the works associated with the Games. Faulhaber and Azevedo (2015) examined all the official requests for expropriation since the then Rio City Mayor Eduardo Paes took office in 2009 and discovered a total of 20,229 households had been affected. The reasons for displacement included works for the Olympic Park, the Rapid Bus Transit (BRT) corridors, works carried out by the secretariat of housing and other secretariats, and those considered 'at risk'. The figure places Paes' mandate as responsible for the largest number of evictions in Rio ever, ahead of even Lacerda and Passos. As a result of these and other developments in the city including police violence, environmental damage and funding shortages, academics, journalists and human rights and other NGOs produced documents with titles such as: The other side of the medal (Bartelt n/d); SMH 2016: Removals in the Olympic City ${ }^{i i i}$ (Faulhaber and Azevedo 2015); and Human Rights Violations in the Olympic City (Fichino et al, 2016).

Bartelt (n/d) compared 2014 with 2016, and identified several threats to democracy through developments in urban planning in Brazil. Faulhaber and Azevedo (2015) contains a preface written by Raquel Rolnik, the United Nations Special Rapporteur on Adequate Housing between 2008 and 2014. During her term in office she investigated developments in several BRICS countries hosting sports mega-events - India, China, South Africa and Brazil - and reported to the UN Human Rights Council. She argues that the absence of information, transparency and participation in decision-making about removals violated human rights in Brazil. Mass removals were taking place as a result of the hosting of sports mega-events, even though this was 'only one moment of (the) wider logic' (in Faulhaber and Azevedo, 2015, p. 12) of opening up frontiers for the expansion of the capitalist market. She considers that the capitalist production of space occurs at the expense of citizen's rights. This means that those 
who lost their homes as a result of decisions made by the hosting organizations do not, in almost all cases, gain. Rather they were marginalized by the reorganisation of urban space as it was occupied and appropriated for the mega-event. The policy was not focused on improving life conditions, respecting rights, and distributing urban space more fairly, but oriented to maximising profits (in Faulhaber and Azevedo, 2015, p. 13). The NGO Justica Global put together a dossier for journalists visiting Rio in 2016 (Fichino et al, 2016) on Human rights violations in the Olympic city. This detailed violations of rights in sport, housing, environment, public spending, urban control, urban mobility, law, city of exception and provided a map of violations for visitors to the city.

The singular case of Vila Autódromo among other favelas, located as it is on the edge of the racetrack designated as the 2016 Olympic Park (see Horne and Whannel 2012: 138-145), illustrates the violations mentioned as a result of Rio 2016. Such was the effort to remove the community that it prompted the assistance of local architecture and planning schools to help the resident's association to develop an alternative proposal for the site's redevelopment (AMPVA, 2012). In demonstrating that the upgrading of the favela did not compromise the work for the Olympic Park, and that it would cost less than the compensation and relocation to another site, the plan won the Deutsche Bank Urban Age Award in 2013. However, the municipality was adamant that it would clear the site, and was included in the contract for the development of the Olympic Park. Different reasons ranging from exposure to natural hazards, environmental damage, event security, the construction of the Main Press Centre (MPC), the BRT corridor, and the duplication of access roads - were alleged at different times without the details and plans being fully disclosing, despite public requests (Silvestre 2016). A six-year long intimidation process and the resulting psychological stress, common in other favelas subjected to similar removals and evictions, led most of the residents of Vila Autódromo to accept removal, leaving only a small group to challenge the municipality's plan. These people were 'rewarded' with the building of 20 new housing units in a radically reduced space for their community surrounded by access roads to the Olympic Park and dominated by a new multi-storey hotel building. They were given access to the housing only a week before Rio 2016 began.

\section{Reports, Denials, Responses and Counter-Responses}


According to Cohen $(2001,51)$ denial is the maintenance of social worlds in which an undesirable situation (event, condition, phenomenon) is unrecognised, ignored or made to seem normal'. Without the opposite of denial, acknowledgement, it is impossible to reach a situation of reconciliation between two or more opposing groups. With mega-event organizers and their representatives we do not often get acknowledgement of problematic situations, but usually denials. The repertoire of official responses and counter responses to the reports about human rights abuses in connection with the mega-events in Brazil has been consistent with that at previous events.

Cohen (1996) describes the techniques of denial that perpetuate human rights violations and responses to reports about human rights abuses. Denial takes three forms:

1. Literal denial - bluntly, nothing is said to have happened. Through discrediting a statement, or the person making the statement, a denial is made without acknowledging 'the facts';

2. Interpretative denial - here it is accepted that something happened but not what is suggested; the statement made is accepted but it is said that it offers an incorrect (biased) interpretation. Hence denial is made through reinterpretation;

3. Implicatory denial - here it is agreed that something happened but that its consequences were not really as bad as claimed and can be justified. The denial accepts the statement but rejects the implications for changes to practice, policy or politics.

Two other responses to human rights reports are (i) the counter offensive, which will be different depending on whether the critical comments are from internal agencies or external agencies, and (ii) partial acknowledgment. Cohen (1996, p. 537) suggests that countering official denial in turn has usually involved advocating one or more of the following strategies: accountability, shame, isolation, economic sanctions, arms boycotts, or cultural (including sports) boycotts. However the deployment of these usually occurs because of changes in the balance of geo-political and economic interests, rather than as a result of an intellectually convincing report or counter response. Government appeals to necessity, security and self-defence are often seen as more 'credible' than 'principled 
insistence on a strict human rights line' (Cohen 1996, p. 539). Appeals to 'abstract principles' look less convincing than technical solutions that routinized human rights abuses, especially when introduced as 'small practical steps'.

Despite this two forms of counter response are often attempted: 'reactive' is intricate and time consuming, possibly going on for years if not indefinitely, whilst 'proactive' will not avoid another round of denials either (Cohen 1996 p. 540). So what is to be done? How to make advances in the cause of human rights abuses connected with sports mega-events? As Downes et al (2007 p. xxvi) note: 'Understanding denial is central to the effectiveness of transitional justice, to the work of human rights NGOs [...] that must overcome it to engage people in their work and to the concept of an international community seeking to assert human rights values'. Equally as Cohen remarked to Laurie Taylor (2007 p. 23) "'The sheer accretion of information about things is not enough"'. Cohen's ideas are highly prescient at a time of the rise 'post-truth' political discourse, accompanied, for example, with the election of Donald Trump as President of the United States of America, in which appeals to 'objective facts are less influential in shaping public opinion than appeals to emotion and personal belief' (cited in https://en.oxforddictionaries.com/word-of-the-year/word-of-theyear-2016 [accessed 10 April 2017]). iv

Irrespective of location, human rights reports on suffering have tended to be presented in a standard way according to Cohen (1996, pp. 519-521). These include: expressions of concern; statement of the problem; setting the context; describing sources and methods; stating detailed allegations; referring to international and domestic law; and seeking required action. Over two decades since his article was published, the reports mentioned earlier about Brazil sustained this pattern.

Despite the powerful conformist tendencies and pressures noted above, the contradictions surrounding mega-events today don't always result in the neutralizing sale of criticism or the containment of its oppositional energy. The more economically monstrous and spectacular that mega-events have become over the past two decades, the more opposition they appear to have generated. Because mega-events are inherently relational in a more broadly global sense than ever before, the nations, cities and INGOS who typically award 
and license these events must now engage with an international cacophony of dissenting voices, with the unlikely prospect that these voices can be completely silenced in the age of global media. As Kevin Fox Gotham (2016, p. 39) observes:

Unlike the past, where opposition to mega-events was often muted or exceptional, today we witness an explosion of unrest and protests led by opposition coalitions dedicated to drawing global attention to the inequities and anti-democratic nature of spectacles.

Sporting mega-events have become especially notable focal points for social criticism and unrest because they provide internationally visible opportunities for critics to protest perceived inequalities, corruption or social injustice by "seizing the platform" that the events provide (Price, 2008; Timms, 2012). Depending on the social and political context of the event in question, criticism can variously be found in large public demonstrations, street art, graffiti, formal reports and popular literature in addition to news reporting, investigative journalism and opinion columns in both mainstream and alternative news media, as well as in a considerable body of academic work. Criticism can also circulate globally in digital form, in dossiers, blogs, and tweets and on activist websites, creating new social and intellectual resources and new networked possibilities for opposition.

The critique of, and moral panic about, sporting mega-events has become an important aspect of globalization because it provides a transnational social and political space for public discussion that exceeds the boundaries of nation states. This lends itself to greater opportunities to evaluate mega-events from multiple standpoints of global justice, postcolonial aspirations and other important ethical, social, political and ecological issues of our time (for some examples of the social movements involved see Harvey et al 2014). Academic discussion of political contestation, interventions and activism has proliferated as a result (see for example Giulianotti et al 2015a and 2015b; Boykoff 2014 and 2016) although sociologists do not have a monopoly over activist engagement, especially in Brazil. ${ }^{v}$ As mega-events have become challenged so their organising bodies (notably, but not solely the IOC and FIFA) have sought to align themselves more with human rights, and sport for development and peace initiatives (Horne and Whannel 2016; see for example Kidd and Donnelly 2000, Kidd 2010). 
Human rights abuses connected with mega-events operate in a smaller time frame than other human rights abuses. This provides less scope for the 'to and fro' of claim and counterclaim to take place. Hence some NGOs have felt that there is a need to intervene at the top-down level and in combination with other 'stakeholders'. Hence the 'Sport and Rights Alliance' (including Amnesty International, the International Trade Union Confederation, Transparency International Germany, Terre des Hommes, and Human Rights Watch) formed in 2015 to address the decision-makers of international sports mega-events and seek to introduce measures to ensure mega-events are always organized in a way that respects human rights (including labour rights), the environment and anti-corruption requirements at all stages of the process - from bidding, through to the development and delivery phase to final reporting (http://www.sportandhumanrights.org/wordpress/index.php/2015/07/06/sport-and-rightsalliance/ [last accessed 5 September 2016]). ${ }^{\text {vi }}$

\section{Conclusion: developing a cultural politics of sports mega-events}

In the past five years, the Winter Olympic Games, the Commonwealth Games, and the Summer Olympic Games have all seen either a low uptake of opportunities to host them, or results from plebiscites or referenda in places as diverse as Munich, Oslo, Edmonton, Vienna, Boston, and most recently Rome, that indicate that politicians and the citizens of certain cities are no longer attracted to hosting them. This does not mean that there are no locations interested in hosting these mega-events, but it is worth considering why this disinclination to host has happened. Possibly the disenchantment toward the hosting of sports mega-events has spread because of increasingly effective symbolic contestation of the promises and rhetoric of mega-event boosters? That is, it is perhaps a sign that the moral panic about mega-events is having an impact (Horne 2017).

It would be wrong to think that this is the end of the struggle over human rights abuses at sports mega-events however. Rather it is better to see it as the next chapter in the struggle. In the current political and ideological climate techniques of denial and the role of the 'merchants of doubt', which have existed for decades, have flourished (Oreskes and Conway 2010). As Cohen (1996) noted simply witnessing the truth through generating and providing video and film evidence of abuses (e.g. via an organisation such as Witness: https://vae.witness.org/) is not straightforward, and accounting (for the truth) has become 
institutionalised. He suggested then that there is a need to better explain human rights norms and develop the 'style, format and genre of human rights' reports (Cohen 1996, p. 543). Uneven power relations continue to structure the field even if the symbolic order constitutes a space of relative autonomy that allows for 'struggles over the sense of the social world' (Burawoy and von Holdt, pp. 15-16). Although the role of academics should not be romanticised, in this context it is vital that researchers, as Kennelly (2016) suggests, provide resources not just for understanding the impacts of hosting sports mega-events on marginalised sections of the community, but also indicate how their research connects with and gives voice to those who do not often get the chance to be heard. This is also necessary to offset attempts at 'astroturfing' - or creating and disseminating fake 'grassroots' opinions (Glaser 2011, pp. 46-51). Astroturfing is no less likely to be used to generate excitement and positive opinions about sports mega-events, as in other commercial or political campaigns.

I welcome the growing awareness of the risks involved with, and the developing critical stance towards, hosting sports mega-events. This trend can be read as an effect, directly and indirectly, leading from the analyses of academic research, and critical investigative journalism, informed by and informing the work of activists. Key features that form the basis for political campaigns about sports mega-events include the following. They are glocal both global and local events with international repercussions. They require early involvement from those likely to be on the receiving end to be effective. The hosting of sports mega-events goes through phases, when they are more in the public eye than at other times and when different issues emerge and can be debated. Campaigns over sports mega-events are symbolic contestations - and therefore the need to win people's hearts as well as minds is important. Campaigns over sports mega-events involve the bringing together of local coalitions and this requires careful consideration. Bottom-up sustainability is better than sustainability promises offered from the top-down. It is vitally important to learn from the experience of other struggles and campaigns.

Worldwide there are an increasing number of critics who attempt to counter bids and contest the ways in which the professionalization of the 'events industry' impacts local decision-making. The questions they raise are not just about the division of costs and benefits of mega-events, but also about their impacts on human rights in cities contemplating bidding for them. 


\section{References}

Adams, A. \& Piekarz, M. (2015). 'Sport events and human rights: positive promotion or negative erosion?', Journal of Policy Research in Tourism, Leisure and Events, 7 (3), pp. 220-236.

AMPVA (2012). Plano Popular da Vila Autódromo: Plano de Desenvolvimento Urbano, Econômico, Social e Cultural, Rio de Janeiro: AMVPA (Associação de Moradores e Pescadores da Vila Autódromo).

Barbassa, J. (2015). Dancing with the Devil in the City of God: Rio de Janeiro on the Brink, New York: Touchstone.

Bartelt, D.D. (n/d). The other side of the medal Berlin: Heinrich-Boll-Stiftung, The Green Political Foundation.

Blackburn, R. (2011). 'Reclaiming Human Rights', New Left Review 69, pp.126-138.

Bowater, D. (2015). 'Brazil Rio: Rare victory for residents in regeneration battle', $B B C$ News, Latin America \& Caribbean, 4 February, Available at:

http://www.bbc.co.uk/news/world-latin-america-31090761 [last accessed 31 July 2015].

Boykoff, J. (2016). Power Games. A political history of the Olympics London: Verso.

Boykoff, J. (2014). Activism and the Olympics: Dissent at the Games in Vancouver and London New Jersey: Rutgers University Press.

Braathen, E., Mascarenas, G. \& Sorboe, C. (2015). 'Rio's ruinous mega-events', in P. Bond \& A. Garcia Eds. BRICS. An anti-capitalist critique, London: Pluto, pp. 186-199.

Broudehoux, A-M. (2016). 'Mega-events, Urban Image Construction and the Politics of Exclusion', in R. Gruneau \& J. Horne Eds. Mega-Events and Globalization: Capital and spectacle in a changing world order, London: Routledge, pp. 113-130.

Brownell, S. (2012). Human rights and the Beijing Olympics: imagined global community and the transnational public sphere. The British Journal of Sociology, 63 (2), pp. 306- 327.

Burawoy, M. \& von Holdt, K. (2012). Conversations with Bourdieu-The Johannesburg moment. Johannesburg: University of Witwatersrand Press.

Cohen, S. (2010). 'The Political Agenda of Moral Panic Theory: Constructing a Sociology of Importance', paper delivered at the 'Moral Panics in the Contemporary World' conference, Brunel University, 10-12 December 2010. Available at http://www.youtube.com/watch?v=xV5-HFqYOPY [last accessed 1st September 2016].

Cohen, S. (2002). 'The cultural politics of moral panics' Foreword to Folk Devils and Moral Panics. London: Routledge. $3^{\text {rd }}$ edition.

Cohen, S. (2001). States of Denial: Knowing about Atrocities and Suffering. Cambridge: Polity Press. 
Cohen, S. (1996). 'Government Responses to Human Rights Reports: Claims, Denials and Counterclaims', Human Rights Quarterly, 18 (3), pp. 517-544.

COHRE (Centre on Housing Rights and Evictions) (2008). One World, Whose Dream? Housing Rights Violations and the Beijing Olympic Games, Geneva: Centre on Housing Rights and Evictions.

COHRE (2007). Fair Play for Housing Rights: Megaevents, Olympic Games and Housing Rights. Geneva: Centre on Housing Rights and Evictions.

Donnelly, P. (2008). Sport and Human Rights. Sport in Society, 11(4), 381-394.

Downes, D., Rock, P., Chinkin, C. \& Gearty, C. (2007). 'Introduction', in Downes, D., Rock, P., Chinkin, C. \& Gearty, C. Eds. Crime, Social Control and Human Rights. From moral panics to states of denial: Essays in honour of Stanley Cohen Cullompton: Willan Publishing, pp. xix xxviii.

Faulhaber, L. \& Azevedo, L. (2015). SMH 2016: Removals in the Olympic City (English translation of SMH 2016: Remocoes no Rio de Janeiro Olimpico) Rio de Janeiro: Morula Editorial.

Fichino, D. Mourinho, G. \& Campagnani, M. (2016). Human rights violations in the Olympic city Rio de Janeiro: Justica Global.

Fraser, N. (1997). Justice Interruptus: Critical Reflections on the 'Postsocialist' Condition. London: Routledge.

Freeman, M. (2011). Human Rights: An Interdisciplinary Approach, $2^{\text {nd }}$ Edition, Cambridge: Polity Press.

Giulianotti, R., Armstrong, G., Hales, G. \& Hobbs, D. (2015a). "Sport Mega-Events and Public Opposition: A Sociological Study of the London 2012 Olympics." Journal of Sport and Social Issues 39 (2): 99-119.

Giulianotti, R., Armstrong, G., Hales, G. \& Hobbs, D. (2015b). "Global sport mega-events and the politics of mobility: the case of the London 2012 Olympics." British Journal of Sociology, 66 (1): 118-140.

Glaser, E. (2011). Get real: How to tell it like it is in a world of illusions. London: Fourth Estate.

Gotham, K.F. (2016). 'Beyond bread and circuses: mega-events as forces of creative destruction', in Gruneau, R. \& Horne, J. Eds. Mega-Events and Globalization: Capital and Spectacle in a Changing World Order. London: Routledge, pp. 31-47.

Harvey, D. (2012). Rebel Cities. London: Verso. 
Harvey, J., J. Horne, P. Safai, S. Darnell \& S. Courchesne-O'Neill. (2014). Sport and Social Movements: From the Local to the Global. London: Bloomsbury.

Hayes, G. \& Horne, J. (2011). Sustainable development, shock and Awe?: London 2012 and civil society. Sociology, 45(5), 749-764.

Horne, J. (2017). 'Sports Mega-Events: Mass Media and Symbolic Contestation', in L. Wenner \& A. Billings Eds. Sport, Media and Mega-Events, London: Routledge, pp. 19-32.

Horne, J. (2007). 'The Four “Knowns” of Sports Mega-Events'. Leisure Studies 26 (1), 81-96.

Horne, J. \& Whannel, G. (2016). Understanding the Olympics (2 ${ }^{\text {nd }}$ Ed.), London: Routledge.

Horne, J. \& Whannel, G. (2012). Understanding the Olympics, London: Routledge.

Horne, J. \& Whannel, G. (2010). The 'caged torch procession': Celebrities, protesters and the 2008 Olympic torch relay in London, Paris and San Francisco. Sport in Society, 13(5), 760770.

Hunt, L. (2007). Inventing Human Rights: A History New York: Norton.

Jennings, A. (2006). Foul! The secret world of FIFA: Bribes, vote rigging and ticket scandals. London: Harper Sport.

Jennings, A. (1996). The new lords of the rings: Olympic corruption and how to buy gold medals. London: Pocket Books.

Kidd, B., \& Donnelly, P. (2000). Human Rights in Sports. International Review for the Sociology of Sport, 35(2), 131-148.

Kelso, P. (2004). "Human rights shadow over Beijing games", The Guardian, 30 August, [available online at http://www.theguardian.com/world/2004/aug/30/china.athensolympics2004; last accessed 2 December 2014].

Kennelly, J. (2016). Olympic Exclusions. Youth, poverty and social legacies. London: Routledge.

Kidd, B. (2008). 'A New Social Movement: Sport for Development and Peace.' Sport in Society: Cultures, Commerce, Media, Politics, 11 (4).

Kidd, B. \& P. Donnelly (2000). 'Human rights in sports.' International Review for the Sociology of Sport, 35 (2): 131-48.

Lenskyj, H. J. (2008). Olympic Industry Resistance. Challenging Olympic Power and Propaganda. Albany: State University of New York Press.

Lenskyj, H. J. (2002). The best Olympics ever? Social impacts of Sydney 2000. Albany, NY: SUNY Press. 
McCann, B. (2014). Hard Times in the Marvellous City. From Dictatorship to Democracy in the Favelas of Rio de Janeiro, Durham \& London: Duke University Press.

Meade, T. (1997). "Civilizing" Rio. Reform and Resistance in a Brazilian City, 1889-1930, Pennsylvania: Pennsylvania State University Press.

Moyn, S. (2010). The Last Utopia: Human Rights in History Cambridge, MA: Harvard University Press.

Olds, K. (1998). 'Urban mega-events, evictions and housing rights: the Canadian case', Current Issues in Tourism 1 (1): 2-46.

de Oliveira, N. G. (2015). O poder dos jogos e os jogos de poder: interesses em campo na produção da cidade para o espetáculo esportivo ('The power of games and the games of power'), Rio de Janeiro: UFRJ/Anpur.

Oreskes, N. \& Conway, E. M. (2010) Merchants of Doubt. New York: Bloomsbury.

Perlman, J. (2010). Favela. Four Decades of Living on the Edge in Rio de Janeiro, New York: Oxford University Press.

Porter, L., Jaconelli, M., Cheyne, J., Eby, D. \& Wagenaar, H. (2009). Planning displacement: The real legacy of major sporting events, Planning Theory and Practice, 10(3), 395-

418.

Price, M. (2008). "On Seizing the Olympic Platform" in Owning the Olympics: Narratives of the New China, edited by M. Price and D. Dayan, 86-114. Ann Arbor: University of Michigan Press.

Ritchie, B. \& Hall, M. (1999). 'Mega-events and human rights', in Taylor, T. Ed. How You Play the Game: the Contribution of Sport to the Protection of Human Rights, First International Conference on Sports and Human Rights, September 13, Sydney, Australia, Sydney: Faculty of Business, University of Technology, Sydney, pp. 102-115.

Robertson, R. (1992) Globalization London: Sage.

Rolnik, R. (2015). 'Preface', L. Faulhaber and L. Azevedo SMH 2016: Removals in the Olympic City

Rolnik, R. (2009). Report of the UN's Special Rapporteur on Adequate Housing as a Component of the Right to an Adequate Standard of Living, and on the Right to Non discrimination in this Context, New York: United Nations General Assembly, $\mathrm{A} / \mathrm{HRC} / 13 / 20$.

Silvestre, G. (2016). 'Rio de Janeiro 2016', in Gold, J. \& Gold, M. (Eds.) Olympic Cities, $3^{\text {rd }}$ edition, London: Routledge.

Simson, V. \& Jennings, A. (1992). The lords of the Rings: Power, money \& drugs in the 
modern Olympics. London: Simon \& Schuster.

Stammers, N. (2009). Human Rights and Social Movements London: Pluto.

Taylor, L. (2007). 'The other side of the street: an interview with Stan Cohen', in Downes, D., Rock, P., Chinkin, C. \& Gearty, C. Eds. Crime, Social Control and Human Rights. From moral panics to states of denial: Essays in honour of Stanley Cohen Cullompton: Willan Publishing, pp. 18-25.

Therborn, G. (2011). The World. A Beginner's Guide Cambridge: Polity.

Tilly, C. (2004). Social Movements, 1768-2004 Boulder, CO: Paradigm Publishers.

Timms, J. (2017). 'The relay of mega-event activism', in N. Salazar, C. Timmerman, J. Wets, L. Gama Gato \& S. Van den Broucke Eds. Mega-Event Mobilities: A Critical Analysis. London: Routledge, pp. 108-127.

Timms, J. (2012). "The Olympics as a platform for protest: A case study of the London 2012 'ethical' Games and the Play Fair campaign for workers' rights." Leisure Studies 31 (3): 355372.

Vainer, C., Broudehoux, A-M., Sanchez, F. \& Oliveira, F.L. Eds. (2016). Os Megaeventos e a cidade. Perspectivas criticas (Mega-events and the city. Critical perspectives). Rio de Janeiro: Letra Capital Editora.

Watts, J. (2013). "Sepp Blatter urges Brazil protesters not to link grievances to football." The Guardian, 19 June [available online at:

http://www.theguardian.com/football/2013/jun/19/sepp-blatter-brazil-football-protests; last accessed 2 December 2014].

Worden, M. 2015. "Raising the Bar: Mega-Sporting Events and Human Rights." Human Rights Watch World Report 2015, [available online at: http://www.hrw.org/worldreport/2015/essays/raising-bar; last accessed 16 March 2015].

Zimbalist, A. (2015). Circus Maximus. The Economic Gamble Behind Hosting the Olympics and the World Cup. Washington, D.C.: Brookings Institution Press.

Zirin, D. (2016). Brazil's Dance with the Devil: The World Cup, The Olympics and The Fight for Democracy. Chicago: Haymarket Books, (revised edition). 


\section{Endnotes}

${ }^{i}$ This article draws upon research carried out in Brazil and the UK since 2010. It develops presentations originally given at the University of Brighton in 2013, the Leeds Beckett University in 2016, and the Federal University of Rio de Janeiro in 2013 and 2014.

ii See for example Barbassa 2015, Boykoff 2016, Braathen et al 2015, Oliveira 2015, Vainer et al 2016, and Zirin 2016.

iii After an area was declared for 'public utility' and a list of properties was published, city officials promptly visited a favela to inform residents of their eviction and to mark houses with painted signs. 'SMH' - the initials of the municipal housing department of Rio de Janeiro - was painted onto the walls of homes in favelas marked for demolition as 'a sort of officially sanctioned graffiti' (Bowater, 2015).

iv Oxford Dictionaries announced that 'post-truth' was the Word of the Year in 2016, defined as '"relating to or denoting circumstances in which objective facts are less influential in shaping public opinion than appeals to emotion and personal belief"' (https://en.oxforddictionaries.com/word-of-the-year/word-of-the-year-2016 [accessed 10 April 2017]).

$\checkmark$ At a conference in Sao Paulo in 2010 that brought together academics and activists from communities preparing to resist the impact of the 2014 World Cup and the 2016 Olympics I identified ' 7 theses on sports mega-events' that I thought might be of value to activists. This amounted to a description of some key features of sports mega-events that I felt needed to be understood as the basis for a political campaign. I am not reporting this involvement for the sake of claiming some kind of direct impact for my research, since I would argue that impact is not achieved though one paper alone but a body of evidence. This evidence has accumulated over the past three decades, and involved other forms of writing than the academic, including human rights focussed reports from NGOs.

${ }^{v i}$ In June 2016 the US-based Institute for Human Rights and Business (IHRB) announced the establishment of a Multi-Stakeholder Steering Committee, chaired by Mary Robinson, the former President of Ireland and UN High Commissioner for Human Rights, working towards making human rights more central to sports mega-events. But this involves representatives of national governments, sports governing bodies, local organizing committees and sponsors (including Adidas, BT and Coca-Cola) as well as trade unions and human rights organizations. Is this too broad a church for an effective strategy? 